Lucas, D. M. \& Fugitt, J. (2009). The perceptions of math and math education in Midville, Illinois. The Rural Educator, 31(1), 38-54.

\title{
The Perceptions of Math and Math Education in Midville, Illinois
}

\author{
David M. Lucas \\ Ohio University Southern \\ Jamie Fugitt \\ College of the Ozarks
}

By means of a qualitative research method known as folknography, a concerted effort was made to discern perceptions of math and math education in the rural Midwest. A community that will be referred to as Midville, located in the state of Illinois, was chosen as the target population for this study. The community and surrounding region stands over one hundred miles from the nearest metro complex. The study was conducted in May of 2006. After completion of the initial field work, data were collected, analyzed, and summarized, producing this document.

\section{Introduction}

A qualitative research method known as folknography was used to investigate the perceptions of math and math education in a small rural Midwestern community. The target population consisted of people residing within the community and county given the pseudonym Midville. Dr. David M. Lucas from Ohio University along with Jamie Fugitt, a mathematics education doctoral student at University of Tennessee at the time of the research, led fourteen undergraduate students from Ohio University into a community in rural Illinois to gather data during May, 2006. The authors were interested in exploring the thoughts, opinions and perceptions of the community residents on three central questions:

1. What are the perceptions of the people concerning math and math education?

2. What is the perceived quality of math and math education in the school districts under consideration?

3. What is the impact of math and math education on the future success of students upon their graduation?

The results of the folknographic research project are presented in this article.

\section{Literature Review}

Although the subject of math education and the associated perceptions seems to be largely uninvestigated, some research does exist. For instance, in the spring of 2004, researchers conducted a survey to gain opinions on the importance of math for career and education opportunities. The research project, entitled Public to Policy Makers: More Math, Please, involved a bicoastal public opinion poll that challenged some popular myths and stereotypes surrounding math. More than $75 \%$ of the 1000 adults surveyed in Massachusetts and Washington indicated a firm belief that all students should take at least geometry and algebra; of these, about a third think all high school students should study trigonometry and calculus. Recognizing a link between math skills and jobs, seven out of ten believed that better math education would provide a critical competitive advantage to their state's economic future (Fraser, Fleishauer, \& O’Conner, 2004).

Additionally, according to the poll, the pop-culture notion of widespread math phobia-an American public that is largely intimidated by mathematics-may hold less truth than is generally believed. Only $14 \%$ of the 1000 adults surveyed by the study acknowledged having a fear of math, and an overwhelming $85 \%$ agreed that gaining math skills remains important (Fraser, Fleishauer, \& O’Conner, 2004).

Mass Insight Education, a nonprofit group focused on improving student achievement, commissioned the survey of 1000 residents in Massachusetts and Washington-states with similar demographics and approaches to school reform-to learn how public attitudes might be affected by efforts to increase students' math capabilities.

The results of the study demonstrated that not only did the public feel relatively comfortable with math, but also, $83 \%$ across both states report that they use math at work or at home often. Moreover, the general public seemed to indicate that math did not seem more difficult to learn than other subjects, although more women reportedly remembered having more difficulty with math in school than men (Fraser, Fleishauer, \& O’Conner, 2004). 
Other findings include:

- Nearly unanimously (31 out of 32), executive respondents believe U.S. students' math skills don't compare well with those of students around the world.

- Only one in five people believes American students do as well at math as other countries' students do.

- The majority of those polled believe that students are in better shape than they were before standardized testing began and they believe that high school exit exams in math contribute to continued improvement in math achievement.

"The message of the survey is clear," said William $\mathrm{H}$. Guenther, president of Mass Insight Education. "The public is ready for leadership in math. Fear of math has been overblown. Residents in these two states could not be clearer on the critical importance of math skills to their economic future - or the inadequate state of current math education in the United States, compared to that in other countries” (Fraser, Fleishauer, \& O’Conner, 2004).

In terms of more specific research concerning perceptions in rural populations, investigators from the Appalachian Collaborative Center for Learning, Assessment, and Instruction in Mathematics (ACCLAIM) reviewed math achievement in young people in rural areas and discovered that "as a whole, in general, with all else statistically controlled, rural youth score higher in math achievement than the national average. Advanced math course offerings in rural high schools are, of course, thinner than in fine suburban high schools" (Howely, Pendarvis \& Gholson, 2006).

In terms of professional development for teachers in rural settings, such training "is generally hard to come by, and rurally-oriented professional development is practically unheard of. Producers of instructional materials in mathematics ignore rural populations because of market considerations since populations are both relatively small in all locales and they are geographically dispersed, though about $20 \%$ of the school population (Howley, Larson, Andrianaivo, Rhodes \& Howely, 2007).

The idea that mathematics might serve the local common good, instead of individualistic aspirations for private gain, or national aspirations for global economic dominion is an idea that finds hardly any foothold anywhere, except possibly within ACCLAIM and within the Algebra Project (Howely, Howely \& Huber, 2005).

One perspective that may be especially difficult for mathematics educators to accept nevertheless provides another alternative to the cosmopolitan agenda. From this perspective, rural communities have the right to decide the extent to which mathematics represents valuable knowledge.
Determinations about the utility of knowledge, then, come from rural understandings of what constitutes the good life, rather than from a cosmopolitan philosophy or (what is much the same thing) professional conceptions (Bush, 2005). This perspective allows for the possibility that rural communities might refuse to devote much attention to mathematics education (Begg, 2004). Three integrated themes emerged from this analysis: (1) mathematics education in rural schools needs to be fixed, (2) good things happen in some rural schools, and (3) fixing mathematics instruction relies on certain practices (Howely, Howely and Huber, 2005).

In Ontario, Canada researchers surveyed teachers, as well as the general public, concerning their perceptions of math and math education. For the purposes of this investigation, the perceptions of the public deserve scrutiny. Investigators surveyed more than 1000 teachers and more than 500 members of the general public. Conducted by professional interviewers using computer-assisted, telephone interviewing technology, the surveys were completed in July, 2004 (COMPAS, 2004). Although the respondents were Canadian, the cultural similarities might render some insights as to the perceptions of math and math education in North America, if not specifically the United States.

The findings concerning the perceptions of the general public in the importance of math and math education included:

- The students tested most recently achieved significantly higher scores in general math skills than those tested only five years ago.

- Respondents perceived a distinction between personal skills and professional skills. The personal skills factor was comprised of skills and appreciation for the arts, athleticism, civic mindedness, and generosity of spirit. Meanwhile, professional skills reflected literacy, work ethic, math, and social/interpersonal skills. Professional skills were perceived to be more important than personal skills to a student's future success (COMPAS, 2004).

In another study performed in Australia, over 1300 students from grades 7 to 11 were surveyed to discover their perceptions concerning the importance of math and math education. The research demonstrated that boys were more interested in math than girls throughout grades 7 to 11 . Boys' and girls' interest in math declined throughout the intermediate and middle grades, reaching a plateau near the end of high school. This research also concluded that students' perception regarding the importance of math declined, especially as the students approached their senior year (Watt, 2004).

Information from international studies such as these conducted in Canada and Australian provide important 
comparison information for U.S. projects in a world of increasing global competition.

\section{The Target Area}

Midville, located in central Illinois at the south end of a large lake, is 100 miles from a metropolitan area of 100,000 people and 115 miles east of St. Louis, Missouri. It serves as the county seat and also has the county's only hospital. With a population standing a little over 5,000 people, Midville remains the largest town in a county containing over 23,000 people according to the 2000 Census (State and County QuickFacts, 2006).

According to the city website, "Corn, wheat, and soybeans make agriculture this area's economic priority." However, approximately $26.1 \%$ of the county population is employed in "production, transportation, and material moving occupations"; another $24.4 \%$ is employed in "management, professional, and related occupations," and an additional $21.4 \%$ make their living in "sales and office occupations" (State and County QuickFacts, 2006). Although farming operations remain important in the minds of the citizens, clearly the community continues to change to meet the current needs and market demands.

The nearby lake serves as a major recreational center in the city and the surrounding area. This 11,100-acre lake provides recreational activities for people including camping, boating, hiking, fishing, and hunting.

Twenty churches are listed on the city website including the following denominations: Assembly of God, Baptist, Catholic, Christian, Church of Christ, Church of God, Church of the Nazarene, Jehovah's' Witness, Lutheran, Methodists, and Presbyterian. The site also lists several civic organizations including local chapters of AARP, American Business Women's Association, American Legion, American Red Cross, Kiwanis, Lions, United Way, Moose Lodge, Rotary Club, and Shrine Club.

A local business college, enrolling approximately 40 students at the time of this study, is located in the town. Other colleges and universities in the area include a junior college (approximately 30 miles away), a small university (35 miles away), and a major Midwestern university (about 40 miles away). The Midville School District, comprised of four schools, serves children living in the town. The percentage of students in the high school meeting or exceeding state standards in mathematics during the 20042005 school year comprised less than the percentage statewide with the school failing to meet the minimum standards required for Adequate Yearly Progress (AYP) as defined by the state. For all other schools in the district, the percentage of students meeting or exceeding state standards in mathematics was greater than those percentages statewide with each school making AYP.

Midville district is classified as a small town district while all other county districts are designated as rural. The county student population is about $97 \%$ white and $100 \%$ of the county teachers are white. Reviewing information available online, researchers found that about $9.1 \%$ of the county population was living below the poverty level in 1999 compared to $10.7 \%$ statewide ((State and County QuickFacts, 2006). However, approximately 31\% of the county students are classified as low-income students as compared to $40 \%$ state wide. The average annual teachers' salary in the county is about $\$ 14,000.00$ below the average teachers' salary statewide. All but one of the five districts employ about $30 \%$ of the teachers with graduate degrees compared with $49 \%$ statewide. One district reports $58.5 \%$ of the teachers having graduate degrees. The following table demonstrates the demographics of Midville.

During the 2004-2005 school years, all the county school districts reported making AYP. This designation requires the satisfaction of several criteria including the following: at least $95 \%$ of all eligible students tested in reading and mathematics; at least $47.5 \%$ of these students meeting or exceeding state standards for reading and mathematics; at least $89 \%$ attendance rate for elementary school districts; and at least $66 \%$ graduation rate for high school districts. In all five county districts $100 \%$ of all eligible students were tested in reading and math. The percentage of students meeting or exceeding state standards for mathematics ranged from $58.6 \%$ to $73.3 \%$. Average attendance rates for the five districts ranged from $94.2 \%$ to $95.9 \%$ while the graduation rate ranged from $92 \%$ to $100 \%$.

All elementary and middle schools in the county reported meeting requirements for AYP for 2004-2005 with children performing well on the state mathematics test. The percentage of students meeting or exceeding mathematics standards was above the state percentages for most county elementary and middle schools. The five county high schools did not perform as well. The percentage of students meeting or exceeding the state standards on the Prairie State Achievement Examination (PSAE) Mathematics exam was less than the state average for every high school in the county. The state reported $52.8 \%$ of the students meeting or exceeding the standards in mathematics while the percentages for the county high schools ranged from $40.0 \%$ to $51.4 \%$. Three of the five schools were reported as not making AYP and one of the schools was listed as receiving “academic early warning status” (Interactive Illinois Report Card, 2006).

While school board records were not available for county school districts, an article in the Midville News provided a summary report of the December 2005 meeting of the Midville School Board. As part of the Integrated School Improvement Plan, the high school principal reported, "We are focusing on a lot of things. Part of the plan is focusing on a continued improvement on achievement testing with a focus on math (England, 2005).” The elementary school principal reported that the school had improved a lot in math the previous year and that continued improvements in math is one of the goals on which the school is working. 
Table 1

Demographic Information for School Districts in Midville County with Comparison to the State of Illinois

\begin{tabular}{lrlllllll}
\hline District & $\begin{array}{l}\text { Student } \\
\text { Enrollment }\end{array}$ & $\begin{array}{l}\text { Low } \\
\text { Income } \\
\text { Students }\end{array}$ & $\begin{array}{l}\text { White } \\
\text { Students }\end{array}$ & $\begin{array}{l}\text { Graduation } \\
\text { Rate }\end{array}$ & $\begin{array}{l}\text { Average } \\
\text { Attendance } \\
\text { Rate }\end{array}$ & $\begin{array}{l}\text { Percentage } \\
\text { Meeting or } \\
\text { Exceeding } \\
\text { State AYP } \\
\text { Standards } \\
\text { for Math }\end{array}$ & $\begin{array}{l}\text { Teachers } \\
\text { with } \\
\text { Masters } \\
\text { Degree }\end{array}$ & $\begin{array}{l}\text { Average } \\
\text { Annual } \\
\text { Teachers' } \\
\text { Salary }\end{array}$ \\
\hline Midville & 1269 & $32.4 \%$ & $98.4 \%$ & $100 \%$ & $95.4 \%$ & $69.9 \%$ & $27.2 \%$ & $\$ 43,967$ \\
District 1 & 980 & $27.2 \%$ & $97.3 \%$ & $95.2 \%$ & $95.9 \%$ & $69.0 \%$ & $58.5 \%$ & $\$ 46,164$ \\
District 2 & 490 & $42.0 \%$ & $97.8 \%$ & $97.8 \%$ & $94.3 \%$ & $58.6 \%$ & $28.9 \%$ & $\$ 36,337$ \\
District 3 & 465 & $28.0 \%$ & $99.4 \%$ & $93.1 \%$ & $95.2 \%$ & $73.3 \%$ & $32.5 \%$ & $\$ 37,645$ \\
District 4 & 439 & $28.7 \%$ & $98.4 \%$ & $92 \%$ & $94.2 \%$ & $71.2 \%$ & $33.3 \%$ & $\$ 39,054$ \\
State & $2,062,912$ & $40.0 \%$ & $56.7 \%$ & $87.4 \%$ & $89.0 \% *$ & $47.5 \% *$ & $49.1 \%$ & $\$ 55,558$ \\
\hline
\end{tabular}

*Minimum State Requirements to Meet AYP

During the 2004-2005 school years, all the county school districts reported making AYP. This designation requires the satisfaction of several criteria including the following: at least $95 \%$ of all eligible students tested in reading and mathematics; at least $47.5 \%$ of these students meeting or exceeding state standards for reading and mathematics; at least $89 \%$ attendance rate for elementary school districts; and at least $66 \%$ graduation rate for high school districts. In all five county districts $100 \%$ of all eligible students were tested in reading and math. The percentage of students meeting or exceeding state standards for mathematics ranged from $58.6 \%$ to $73.3 \%$. Average attendance rates for the five districts ranged from $94.2 \%$ to $95.9 \%$ while the graduation rate ranged from $92 \%$ to $100 \%$.

All elementary and middle schools in the county reported meeting requirements for AYP for 2004-2005 with children performing well on the state mathematics test. The percentage of students meeting or exceeding mathematics standards was above the state percentages for most county elementary and middle schools. The five county high schools did not perform as well. The percentage of students meeting or exceeding the state standards on the Prairie State Achievement Examination (PSAE) Mathematics exam was less than the state average for every high school in the county. The state reported $52.8 \%$ of the students meeting or exceeding the standards in mathematics while the percentages for the county high schools ranged from $40.0 \%$ to $51.4 \%$. Three of the five schools were reported as not making AYP and one of the schools was listed as receiving “academic early warning status” (Interactive Illinois Report Card, 2006).

While school board records were not available for county school districts, an article in the Midville News provided a summary report of the December 2005 meeting of the Midville School Board. As part of the Integrated School Improvement Plan, the high school principal reported, "We are focusing on a lot of things. Part of the plan is focusing on a continued improvement on achievement testing with a focus on math (England, 2005).” The elementary school principal reported that the school had improved a lot in math the previous year and that continued improvements in math is one of the goals on which the school is working.

At the time of this study, mathematics education seemed to be attracting a great deal of attention in the county. It became clear in the preparation phase of the investigation that it would be both interesting and informative for folknographers to listen closely to the residents of this area to determine their perceptions of mathematics and mathematics education in this community.

Midville offered insights into the perceptions and attitudes of rural communities, struggle with changing realities, adherence to agrarian traditions, and attitudes toward traditional public education, while they seek to maintain and grow the peaceful living conditions for which the region is known. Midville was selected as a suitable target for this qualitative study. The voices of the folk in this region could provide insight into the perceptions held concerning math and math education and be compared to perceptions discovered in other studies.

\section{The Design}

This study follows the pattern of a similar study previously conducted by Ohio University Southern and the International Institute of Folknography on behalf of the Appalachian Collaborative Center for Learning, Assessment 
and Instruction in Mathematics (ACCLAIM) in Appalachia in March, 2004. The study sought to uncover the perceptions of math and math education in Appalachia. The results were published and math educators around the country continue to study and consider the findings (Lucas, 2004). The implications and impact of the previous research led to this study.

After a period of preparation, the research team entered the field. This team, directed by Dr. David Lucas, consisted of him, Jamie Fugitt, and fourteen undergraduate students. Initially, the team went to work setting up the computer writing lab. After a visual assessment, the city was divided into six sectors for an organized approach. A preliminary survey was used to gather benchmarking statistical data (see Appendix) and to open respondents up to the possibilities of a folknographic method of interviewing. Prior to the journey, all team members were carefully trained in the principles and procedures of folknographic research. These principles and procedures included informing participants of their rights to refuse participation.

Upon subdividing into seven field teams, the folknographers canvassed the entire community of Midville in an intensive research effort. County residents visiting or shopping in Midville during the study were not excluded. After completing an initial survey, respondents were politely invited to participate in interviews for the purpose of acquiring additional qualitative data. In keeping with the principles of folknography, the interviews prompted narratives, written for the purpose of giving voice to the participating folk (Lucas, 2005).

\section{The Findings}

Folknographers entered the field in May of 2006 and performed a focused, intensive field research project in order to discover the perceptions of math and math education in Midville. The teams divided the community into six zones and went door-to-door collecting data via short surveys and seeking respondents for interviews for the purpose of discovering the perceptions of the folk. Using folknography as the method and a design similar to the previous project executed in Appalachia, the research team successfully interviewed 148 respondents and surveyed 1358 individuals (Lucas, 2004). The research team facilitated four focus groups and two plenary sessions. These efforts produced a satisfactory amount of qualitative data for analysis.

Concerning math and math education, representative folk in Midville think:

\section{Young People Can't Do Arithmetic}

The folk from Midville consider math to be an important tool for use in everyday life circumstances. Yet, many adults believe that the youth of Midville need to rediscover the skills of basic arithmetic in order to add, subtract, and solve everyday mathematical problems. In fact, analysis of the qualitative data from this research reveals that the older adult (seniors) folk of Midville may believe that mathematical proficiency is demonstrated solely by basic computational skills. Consider these examples lifted out of folknographic narratives from the project-the interviewers' names have been replaced by initials in order to maintain the integrity of the study:

\section{Simple Math Example One}

I enter the shop and immediately spot him; his rotund figure fills the aisle behind the counter. He looks me over as though I do not belong in this type of store. He does not smile or greet me readily. Instead, he stands with his hands inside the slanted pockets of his size 3XL bibs, left unbuttoned at the waist for obvious reasons. He peers through thick glasses and finally he speaks-but only after I greet him.

The poor man seems even more befuddled when I tell him the reason I stand before him. "Math!” he bellows. "Let me just tell you something about math...I have a thirteen-year-old granddaughter who can't add two and two! She doesn't know diddly-squat about math and she's a 'B' student!' Without time to take a breath he continues, "What these schools need to do is throw away the d--- calculators and get back to teaching the basics. Teach these kids how to do math on paper first - then and only then should they be allowed to use calculators!” (Excerpt from a narrative by TSI)

\section{Simple Math Example Two}

He understands why I am here to speak with him, and he too, is anxious to get on with our dialogue. He shares his staunch belief in the importance of math... and the lack of math education in the area. "Kids just don't have it,” he says. He goes on, "Oh a few do, but I'd say $80 \%$ are crippled by math incompetence.”

As he begins again, he shakes his head and says, "Let me tell you something that took place shortly after I bought this restaurant. I decided I would offer a 10\% discount to senior citizens. When the customer approached the register to pay for his meal, the problem surfaced. The young waitress came to me and questioned the discount." He leans forward for emphasis and says, "I reminded her of our policy to give senior citizens a $10 \%$ discount.”

"How do I do that?" she asked.

“I was stunned! I couldn’t believe what I was hearing. I explained that all she had to do was move the decimal point over one place. She was as shocked to find out how simplistic the process was as I had been when I 
found out she didn't know how to do the math in the first place! So, as I see it," he says, "the problem is that kids these days don't learn on paper. They can only solve a math problem with a calculator in their hands.”

"Students amaze me," he says. "I once had an Honor Student who couldn't do basic math, and I do mean basic math. While on break one day, she sat with her checkbook in hand and looked up at me and asked, what's thirty-seven minus twenty-five?" With sad eyes, he says, "Kids have absolutely no critical thinking skills. They have no idea how to problem solve." (Excerpt from a Narrative by TSI)

\section{Simple Math Example Three}

I ask him about his math teachers in school and he exclaims, "My teachers were real nice and taught me a lot. But, I'm afraid that these young people aren't learnin' from their teachers." My eyes widen as he continues. "These kids today wouldn't be able to do math if they didn't have an addin' machine. They can't give you the right change if the addin' machine breaks down, and they don't know what to do if I give them an odd amount of change for a single bill back. They can't figure change for some reason.” (Excerpt from a narrative by $\mathrm{CB}$ )

\section{Simple Math Example Four}

He speaks with a twang in his voice, "I asked my young step-sisters what 9 x 9 was and they couldn't do it. My sister graduated from college, and she still sends her checkbook to my mom cuz she can't balance a (expletive deleted) checkbook. I mean if you can't use numbers, your s--- outta luck," he says while he shakes his head. (Excerpt from a narrative by CB)

\section{Simple Math Example Five}

After I establish some credibility with the two ladies, they both declare that they "have children and grandchildren." They tell me, "We have a very difficult time when trying to understand the math that the grandkids bring home," which they referred to as "new math." They also add that "we see the trouble that technology plays in today's world. Our kids are too dependent on calculators and computers," Woman Two contributes. "We talk about our kids and their inability to do basic math like making change in a restaurant all the time." They both see math as something we use every day and something that schools need to teach by returning to the basics. (Excerpt from a narrative by CQ)
Perhaps this inability by youth to do simple mathematical computations is related to responses to survey statement number six- - I use math in my life every day." When asked to respond to this statement, only $79 \%$ of youth respondents indicated agreement with this statement, with $94 \%$ of adult respondents and $91 \%$ of senior respondents, respectively, indicating agreement with this statement. The percentage of youth who fail to use math daily in practical activities, or at least fail to recognize its use in their everyday lives, may contribute to some youths' inability to correctly carry out simple mathematical activities such as mental computation and counting change (see Figure 1 below).

In all of these examples the folknographer is compelled to infer that the respondents fail to see a difference in math and arithmetic. Then, in view of this evidence, the novice concerning math feels compelled to ask, "What is the difference between math and arithmetic?" For the answer, we turn to Illana Weintraub (2004) who spent most of her life teaching high school math. In responding to the question as to the difference between math and arithmetic she writes,

My favorite quick answer is that arithmetic is to mathematics as spelling is to writing.

The dictionary definitions of these two bodies of learning are:

a.rith $\cdot$ me $\cdot$ tic

(1) the branch of mathematics that deals with addition, subtraction, multiplication, and division, (2) the use of numbers in calculations

\section{math $\cdot e \cdot m a t \cdot i c s$}

(1) the study of the relationships among numbers, shapes, and quantities,

(2) it uses signs, symbols, proofs, and includes arithmetic, algebra, calculus, geometry, and trigonometry.

Having spent most of my life teaching high school math, it was disheartening to hear my uncle say that what I am teaching is not real math-his world was teaching the math of particle physics to advanced graduate students at Stanford University. Only a handful of people in the world understood the papers he wrote. His definition of arithmetic is that it is structured and that math is not-in his mind, counting through calculus is arithmetic. The theoretical math in his papers was gibberish to me but symbolic prose to him-the marriage of math and science. From this point of view, until you get to advanced physics, the math is not real math. Perspective is everything.

In conclusion, arithmetic uses numbers and mathematics uses variables - each discipline has its own complexities and thought processes. 
The logical conclusion here reveals the need for the math community to better explain the differences and relationships between arithmetic and math. If indeed, arithmetic is to math as spelling is to writing, then math educators need to develop strategies to educate adults in the Midwest regarding the differences, making a case for emphasizing mathematics and not just arithmetic.

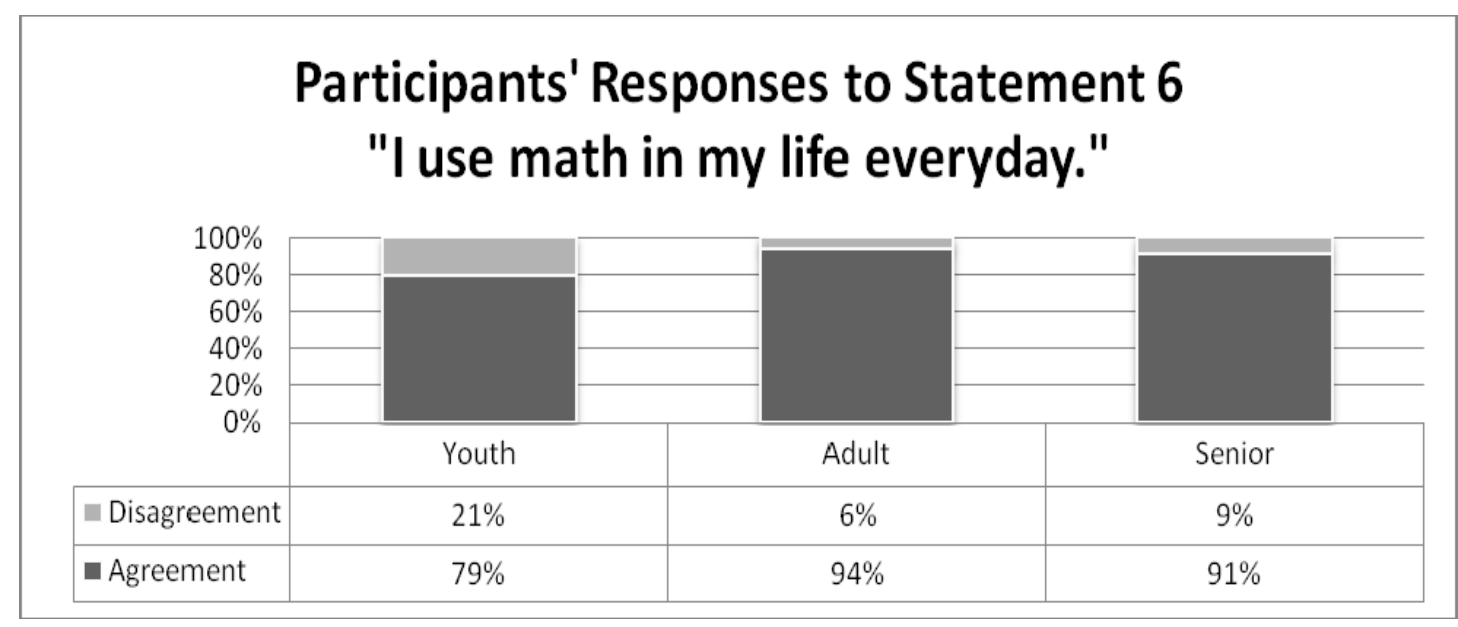

Figure 1. Participants’ Responses to Statement Six ( $\mathrm{N}=1358)$

\section{Too Much Technology!}

The adult folk interviewed hold the basic perception that too much technology can have a significantly negative impact on the developing minds of students in the Midville. The respondents indicated that, especially regarding arithmetic, the students need to learn to solve problems in their heads and on paper before they solve them with their hands and fingers --using the keyboards of electronic gadgets. Consider these representative narratives:

\section{Too Much Tech Example \#1}

The kids don't make the situation any better, according to him. "Kids today just don't give a d---." He tells me how his generation did so much for this country and the environment. He sees the importance of making math required for all students. He thinks that all the basic math (just a glorified sort of algebra) needs to be mandatory at all levels. The students should not be allowed to use calculators or computers until they have a grasp on the material.

"Kids today are just lazy. They want to use their gadgets instead of their brains. We gotta reverse this trend before we get left in the dust by the Europeans and the Chinese!” We talk about urban versus rural education. He sites that there are definite differences from location to location. He says that he heard on the news that teachers in Florida are considering not teaching kids about snow because they never get it down there. He said, "I'll have to check his facts, but that's just one example of the different types of education you can get from place to place.” (Excerpt from a narrative by CQ)

Too Much Tech Example \#2

Two welders speak about the importance of math. Welder \#2 jumps into the conversation: "Yeah, I like welding." He supports Welder \# 1 because of all he has said. I ask Welder \# 2, "Were you successful solving math problems in school?" "Yes, but I haven't been in school since '85. It was different back then.” I ask him to talk about his math experience in school and why it was different. "I had good math teachers; I learned how to do basic everyday things. Now they don't teach that. Now they teach the advanced stuff, but the kids can't do simple things. They can't make change; they don't spend enough time on the basics. The kids today use gadgets but can't do simple math problems. They ought to learn how to solve the stuff first then use the machines." Welder \#1 adds his comments: "The kids need the basics. The basics are important. Teachers start teaching advanced stuff before kids understand the basics. The kids use the machines before they can use their heads. That's just no good for what a person needs in a job. You have to learn to think." (Excerpt from a narrative by EM)

Too Much Tech Example \#3 
She giggles to herself as she thinks of the many times she has needed good math skills. She says that "on several occasions, my friends and I would go shopping and would have a difficult time figuring out the discounts offered." She says, "We would whip out our cell phones and do the calculations so that we'd know what the price should be. We'd use that little calculator, clicking those keys like sixty." She jokingly admits how sad that is. "We can't do the math without those little keys. We need to learn how to do that in our heads, right?” (Excerpt from a narrative by $\mathrm{HH}$ )

\section{Too Much Tech Example \#4}

I ask about her thoughts on technology and math and she answers briefly, "In some ways I think technology is good. But, I think they still need to read books. You know, the students need to be able to solve the problems so they can solve difficult situations in life. We can't use machines to teach us how to live. We can't depend on gadgets. We have to depend on each other." (Excerpt from a narrative by RW)

\section{Too Much Tech Example \#5}

We ask his thoughts and opinions about technology in the math classroom. His reaction is quick as if he was prepared for this particular question. "I think technology should be playing a role, but I'm concerned that we are already past it being a play toy or just for entertainment. I think we have a long way to go incorporating technology in our classrooms. We need to figure out a way in which technology can assist in learning rather than just providing final answers or checking answers. Somehow we have to make technology a teaching instrument." (Excerpt from a narrative by RW)

The folk interviewed seem to agree with one voice. The use of technology should be used as an enhancement and teaching tool in education. These respondents seem to echo the recent findings of a study completed in Germany by MacDonald (2004):

For all the schools and parents who have together invested billions to give children a learning edge through the latest computer technology, a mammoth new study by German researchers brings some sobering news: Too much exposure to computers might spell trouble for the developing mind.

From a sample of 175,000 15-year-old students in 31 countries, researchers at the University of Munich announced in November that performance in math and reading had suffered significantly among students who have more than one computer at home. And while students seemed to benefit from limited use of computers at school, those who used them several times per week at school saw their academic performance decline significantly as well.

The German study stands out on account of two features: its unusually broad, international sample and its bid to isolate computers as a performance-shaping factor. Mindful that computers are common among affluent families, whose children often outperform more than disadvantaged ones, the University of Munich researchers controlled for such variables as parents' education and working status.

When computers were removed from the equation, having more than one computer at home was no longer associated with top academic performance. In fact, the study says, "The availability of computers at home seems to distract students from learning." Computers seem to serve mainly as devices for playing games.

To hear new questions raised about the educational value of technology is music to the ears at the Waldorf schools, an Association of 350 schools where students don't touch computers until the 11th grade. There the priority lies with training students to think, says Patrice Maynard, leader for outreach and development, because problem-solving and creativity lead to success and a joyful life (MacDonald, 2004).

\section{Math Makes the Career}

During the research field work, the folk of Midville made the connection between acquiring math knowledge and achieving a dynamic career. No matter the age, most of those interviewed confirmed the importance of math and the need to study math even if the respondent did not like math as a subject. In Midville none of the youth respondents talked about math as a way out of the community or region. The youth talked about going to college, but none of those interviewed seem to seek an escape from their home town environment. The respondents believe in the value and power of having math skills. Consider these examples from recorded narratives:

\section{Math Makes the Career Example \#1}

She explains to me the importance of math in her daily activities. "I think that math is important in everyday life. It helps me when I go to the store or when I do my checkbook. I use it all the time," she says as she constantly twirls the long green plant stem in her hand. (Excerpt from a narrative by CB)

\section{Math Makes the Career Example \#2}

She asks him about what he feels about math. He says, "I love it. Where would I be without it? If I couldn't 
figure, I wouldn't be in business; I'd probably be on welfare," he says. (Excerpt from a narrative by CB)

\section{Math Makes the Career Example \#3}

"I use math everyday when I balance my checkbook or pay my bills. I do it all in my head and then use my calculator to check out my work." She takes great pride that she knows how to do these things. She again adds her hope that the future generations will at least learn the basics. She has a fear that our technological society will collapse on itself and then we'll be set back a hundred years. "Kids need to understand how important math is for their daily lives. We ought to have a math fair or something with games, prizes, and scholarships. Kids need to feel the excitement of math in their lives.” (Excerpt from a narrative by CQ)

\section{Math Makes the Career Example \#4}

It is not something that she enjoyed in school, but she would take geometry (and all of the other math classes) even if they were not required. She sees the importance of math. She knows that it is something that everyone uses every day. She uses it when she goes to the store or works the concession stand. "I tell my kid's everyday that a good education in math will change their lives and give them a promising career. We all have to do things we don't like. Even if you don't like math you need to take it, study it, and make it an important part of your life.” (Excerpt from a narrative by CQ)

\section{Math Makes the Career Example \#5}

He says "I didn't like math in high school, but I do now. At the time, I couldn't see the point.” He goes on to illustrate about how math makes his career. "I'm a truck driver" he declares proudly yet humbly at the same time. "I use math all of the time at work." $\mathrm{He}$ explains that with truck driving, the driver must figure percentages, pay per mileage, fuel per mileage, distance, time, and so on.

"I only took basic math in high school", he explains. I look over at his wife. She completes the survey. She hands it to me smiling; happy to contribute. As I ask him questions, I keep glancing over at his wife, including her in the conversation with my eyes. She seems uncomfortable in talking, so I concentrate on him.

"I finally took an algebra class" he continues, "but that was in college." I ask him what he had taken in college, and he explains, "I originally tried for an associate in business, but decided it wasn't for me about a third of the way through. I couldn't pass all the classes. But I learned a lot!” I become sad for him, but I try not to show it. I don't want to display the pity I feel for him. "I wished I had taken more math classes," he admits. "I know I'd have a better job. Don't get me wrong, trucking's ok. But, I could teach I think.”

I see him start to think more deeply about math, life, his career, and his future. "I guess a person has to take all they've learned and put it to use. I use what math I have." He may have been thinking of where he would be if he had more. Nevertheless, he seems to have a good life: a beautiful family, a steady job, and he enjoys the nice afternoon outdoors. His hands appear rough, his arms ripple in his shirt, and his face beams red with sun through countless days of driving his truck. His voice resonates with mellow tones as he speaks. His smile speaks volumes.

"I have my math, my family, and my job. What else could I want?” I sense an inner confidence in him as we finish the interview and we exchange smiles. I say goodbye but even as I write this narrative his smile remains with me. Strange how talking about math can draw people together! (Excerpt from a narrative by $\mathrm{HH}$ )

\section{Math Makes the Career Example \#6}

"Math is important. It's everywhere. You can't move up without it." the father declares flatly. He says, "I work for Caterpillar and math is very necessary for this line of work. My son works as a corrections officer and uses counting every day." As with most of our participants, the father says that, "the math becomes increasingly harder with each grade and eventually students get behind. The reason is not necessarily because of the teacher but more of from a motivational standpoint where kids lose interest. It's hard making math seem like fun or a game. It's repetition.”

Both men seem to consider themselves to be successful at solving math problems, but also contend that computers have taken many peoples' math skills away. The son says, "When I was in school I probably wouldn't have taken math if I didn't have to. But when after maturing I probably would have realized that no math is a mistake, but I couldn't take the classes then. I'd be out of luck."

The father chimes back in, "Math is important to daily life. Without math cashiers can't even make change. Hey, besides, having a lot of math is good for your resume! You make half the money with less math education. So, tell your friends at your college: study math and make money!" (Excerpt from a narrative by RM) 
The folk interviewed indicated that, even though many of them (youth and adult) fear math, they still need math to achieve their hopes and dreams. The respondents recognize the need, the value, and the potential of a strong math background. They echo Snyder's sentiments on education and change:

Think about how mathematics has changed over the past few decades. Think about how there has been, and rightfully so, a greater emphasis on mathematics and science. In our technological world there is an ever greater need for students to graduate in those fields, and that need will not go away. In fact, the future top careers will go to the students prepared with the skills that they learn in their math and science classrooms (Snyder, 2006).

This belief that mathematics opens more career opportunities is also evidenced by participants' responses to survey item number seven: "A person can get a better job if he/she has good math skills." Approximately 95\% of respondents agreed or agreed strongly with this statement while only about $6 \%$ of respondents disagreed or disagreed strongly with the idea that possession of good math skills can lead to a better job (see Figure 2 below).

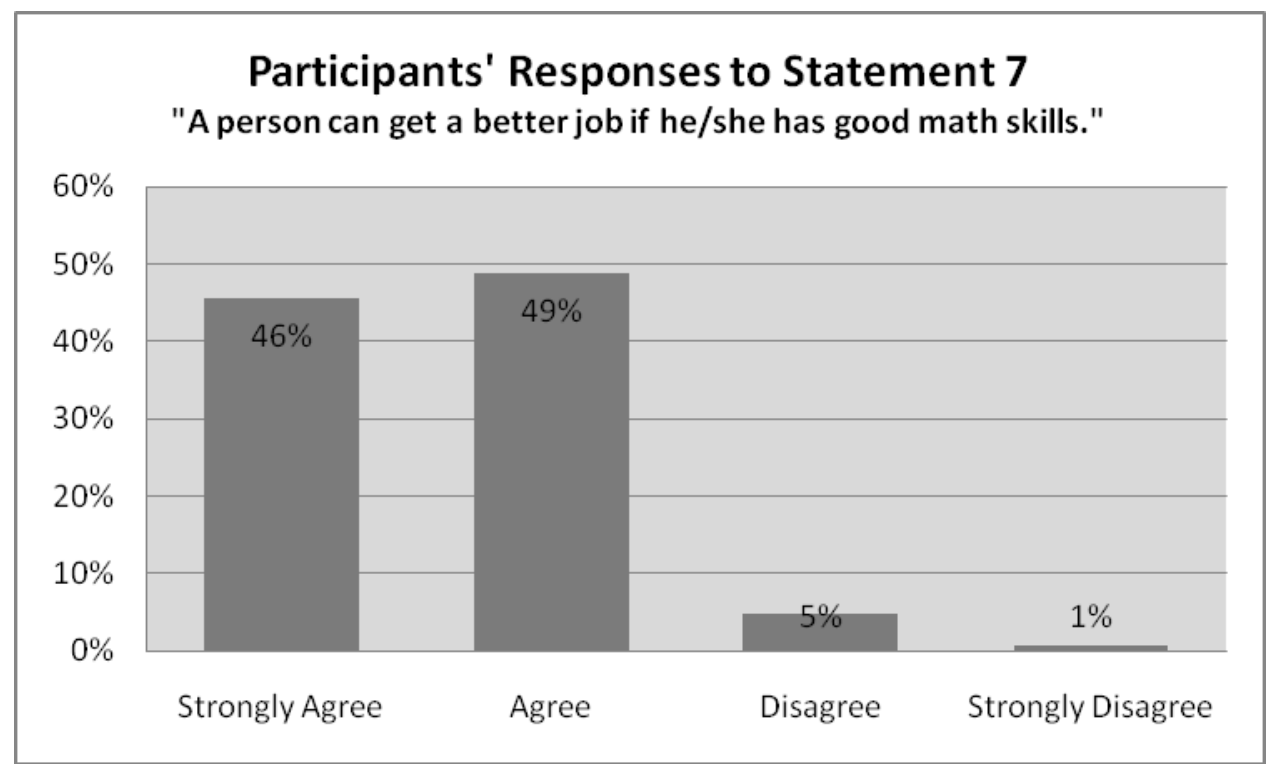

Figure 2. Participants’ Responses to Statement Seven $(\mathrm{N}=1358)$

The possibility that advanced math skills improve career opportunities is shown in participants' responses to survey item number ten-"Advanced math skills can improve employment opportunities in this area." Of the respondents surveyed, 82\% agreed or agreed strongly with this statement. Only $18 \%$ of respondents disagreed or disagreed strongly to this statement (see Figure 3 below). 


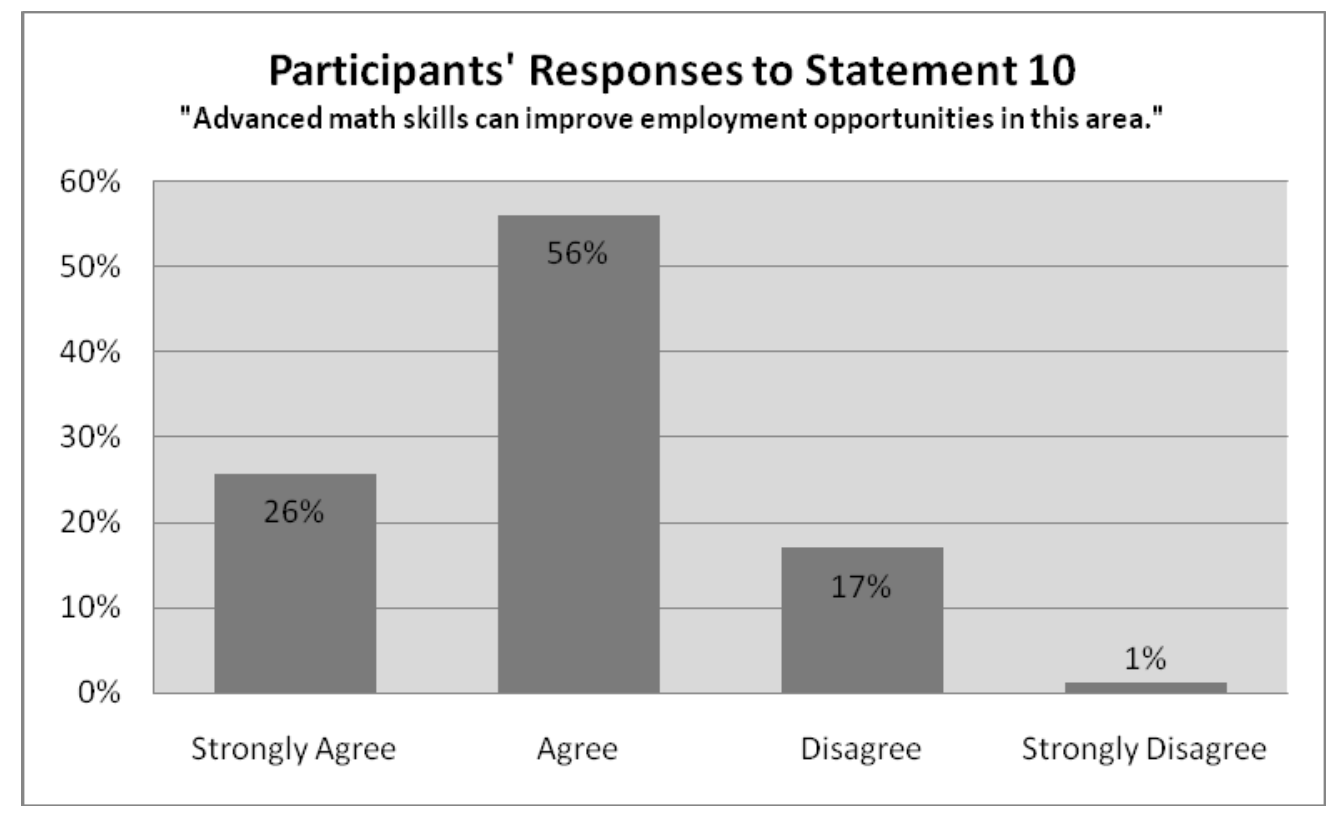

Figure 3. Participants’ Responses to Statement Ten $(\mathrm{N}=1358)$

Responses to statement twelve-"Few jobs in this region of the country require advanced math skills," provide additional insight. Data show about $50 \%$ of the participants agreed or agreed strongly with the statement while about $50 \%$ disagreed or disagreed strongly. The belief of $82 \%$ of the participants that advanced math skills can improve employment opportunities, even in their own location, is interesting juxtaposed next to the response that about $50 \%$ of the respondents believe that few jobs in their area require advanced math skills (see Figure 4 below).

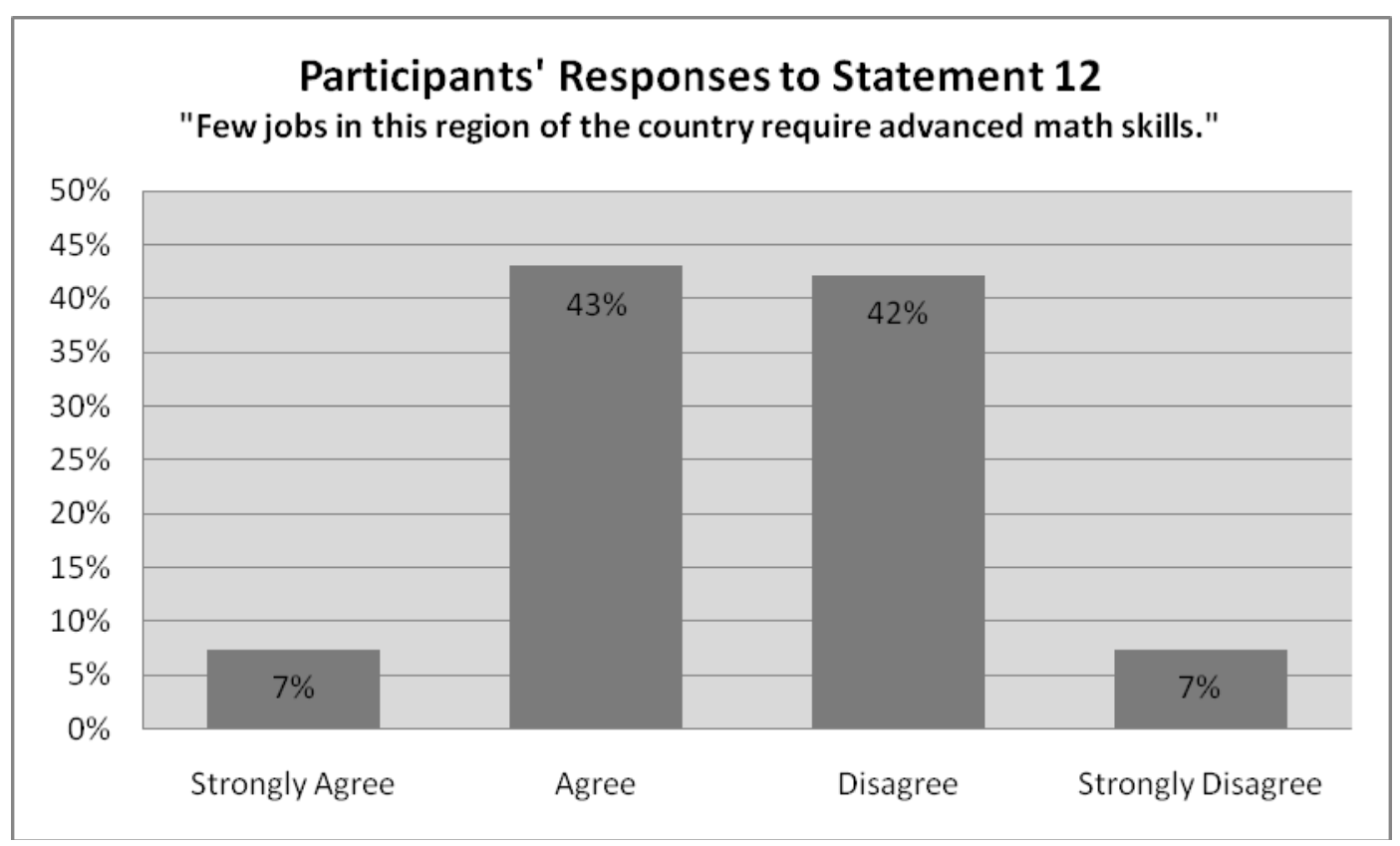

Figure 4. Participants Responses to Statement Twelve $(\mathrm{N}=1358)$ 
In response to statement nine-_Learning math skills is important for the future," participants further indicated their perception of value for mathematics. Data demonstrates
96\% of respondents agreed or agreed strongly with this statement while $4 \%$ of respondents disagreed or disagreed strongly with this statement (see Figure 5 below).

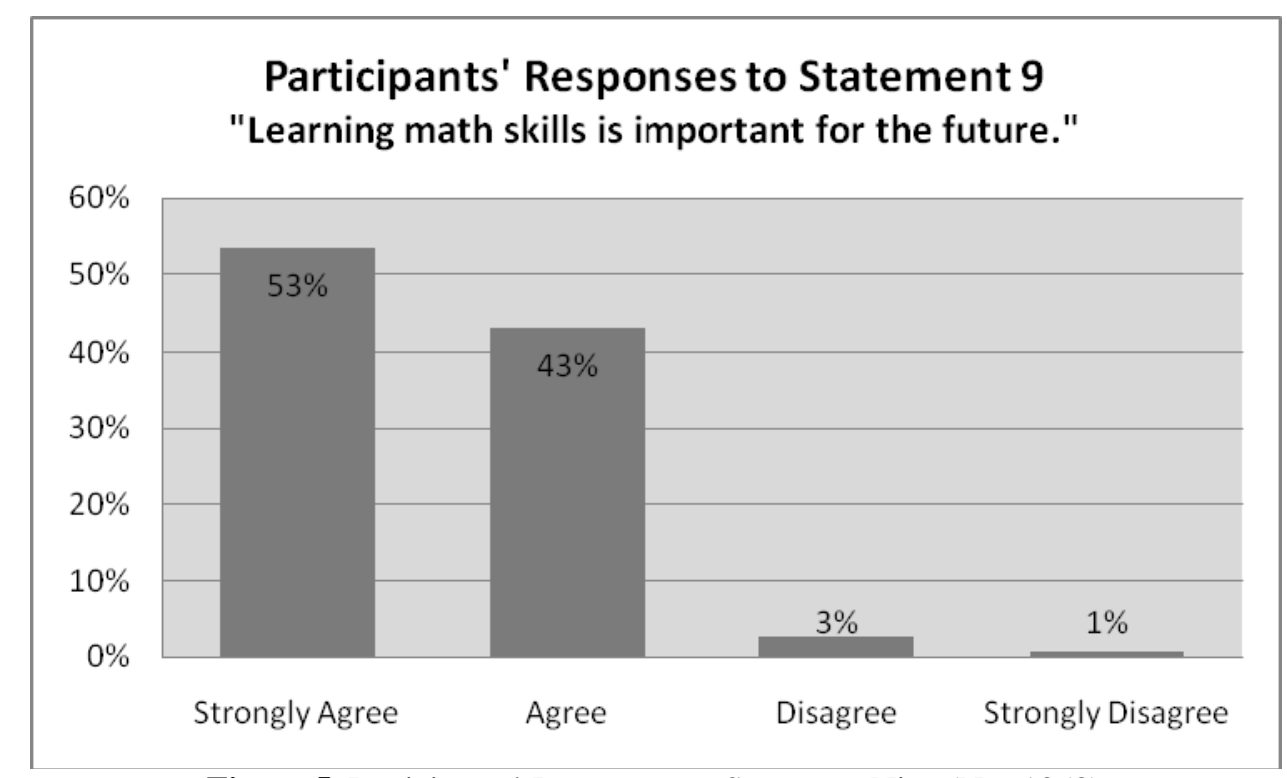

Figure 5. Participants’ Responses to Statement Nine $(\mathrm{N}=1358)$

Participants' responses to these statements relating math skills and employment opportunities varied little according to age groups. However, responses to each of statements seven, nine, and ten were less positive for youth than for both adult groups. For example, 92\% of youth were in agreement with statement seven indicating belief that a person can get a better job if he/she has good math skills. Ninety-six percent of all adults strongly agreed or agreed with this statement. Similar difference between youth and adult responses occurred with regard to statement ten, stating that advanced math skills can improve employment opportunities in the local area. Seventy-eight percent of youth participants agreed or strongly agreed with this statement while $83 \%$ of all adult participants agreed with this statement (see Figure 6 below).

Participants came to this knowledge that math is important to one's career in spite of feeling alienated by the math education process because of the personality of the teachers. They instinctively recognize the need for math by peering through the challenges of their lives. This is a powerful endorsement for math education. In a way, these comments may be like preaching to the choir. Probably most math enthusiasts and educators realize that better employment opportunities come with stronger math skills.
Yet, the respondents in Midville came to this knowledge through experience and observation.

\section{Perceptions of Personality}

Many of the folk in Midville responded to the math questions by mentioning the negative attitudes, actions and behaviors of math teachers. In a previous study on the perceptions of math and math education in Appalachia, Lucas (2004) numerous respondents complained of teachers with poor attitudes and classroom demeanor. The respondents from Midville echoed some of the same sentiments as they explained:

\section{Personality Example \#1}

I ask her about the teachers and she says, "The math teachers...they never seem to make it real ...there is no application to what they teach," she shakes her head and looks over towards the purses. "I think math teachers live in their own world and they can't seem to explain to us where that world is." She giggles. "They need social lessons before they go and teach school." (Excerpt from a narrative by CB) 


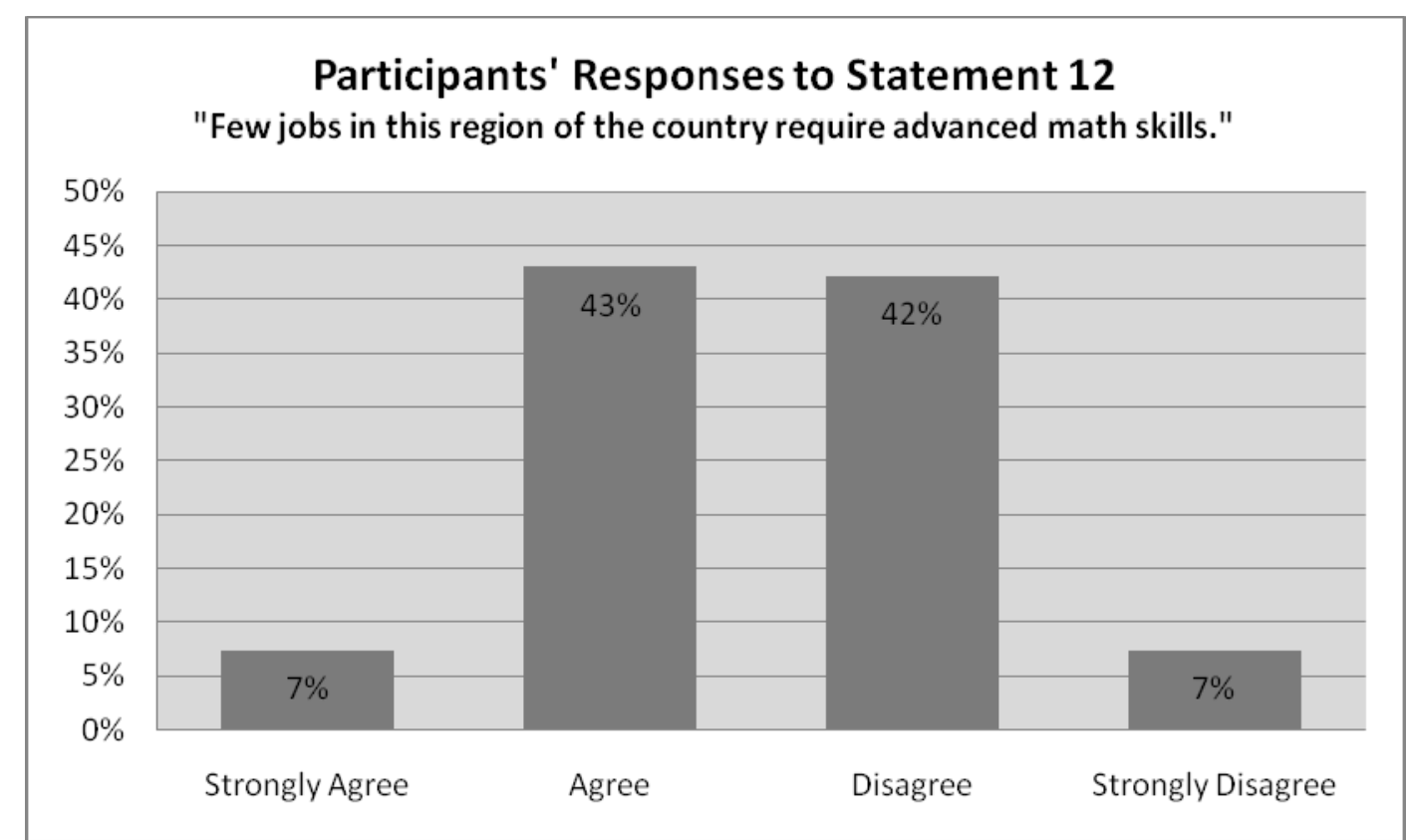

Figure 6. Participants' Responses to Statements Relating Math Skills and Employment Opportunities by Age Groups $(\mathrm{N}=1358)$

\section{Personality Example \#2}

He immediately volunteers the information that he does not like math and that he cheated his way through his high school math classes. He tells me that his math teacher was not a bad teacher, but that he was overbearing and simply not likeable. "There are not too many people in my life that I really haven't liked and he is one of them" he says. (Excerpt from a narrative by TS)

\section{Personality Example \#3}

She tells us how the teachers in her high school did not give her enough one-on-one time and that would have really helped her. This happens to be the problem that her kids also face. They have teachers that do not care if the kids learn the material, they just hope to collect a paycheck and get their summers off for vacation. (Excerpt from a narrative by TS)

\section{Personality Example \#4}

I want to know what she thinks of the math teachers that she had in school. She tells me, "My geometry teacher was horrible at explaining problems. She would just come and work the problem for us. She knew how to do it, but she could not come down to our level and teach us how to solve problems. We could never measure up to her expectations. It was awful!” (Excerpt from a narrative by TS)

\section{Personality Example \#5}

"Look," he says to me as he leans over his corn planter, "I'm not an educated man. I don't have a college education. I've farmed all my life. But I do know some things about life. One thing I know for sure is that you can't go 'round yell'in at kids and get them to learn. We got a math teacher in this school and he yells at everyone. He's a miserable man and he makes the kids miserable. He'd make you miserable in any other class but it just so happens he teaches math. My wife and I go to church every Sunday. None of the Sunday school teachers yell at the kids. So, they laugh and smile and learn things. Then, these same kids go to school, get yelled at, and hate math and we wonder why? Not me. I know why. My math teacher was mean. He was a tyrant. So, that's what I think is wrong with math in schools. Math teachers need to smile and enjoy teaching math so we can all enjoy taking it." (Excerpt from a narrative by DML)

\section{Personality Example \#6}

"Again I say, no one teaches them to think. They are forced into textbook math and that just doesn't work for everyone.” He closes by rewording an earlier thought. "Teachers have got to step over the line-work outside 
the box. If they will just teach the student and not teach to the test, the tests will take care of themselves!" (Excerpt from a narrative by TSI)

\section{Personality Example \#7}

He says he is successful at solving math problems most of the time. Yet, he says math is hard for him because of his math teacher. "She's terrible! She either over teaches or under teaches everything. She doesn't give us enough to study. Most of the people in my math class are failing. We're all confused. She gripes at us but we don't understand what she wants." He says they're not allowed to use calculators in class and that they are all highly discouraged. (Excerpt from a narrative by EM)

The data indicates that personality characteristics of teachers play an important role in the classroom environment for many students. Certainly, this data does not implicate all math teachers, but the fact that these comments bubbled up in the interviews should give cause for pause to those who train math teachers or those who aspire to teach math. Students inhibited by the prospects of math make personality judgments about the math teacher the same as any other instructor. In other words, according to these findings, math teachers must seek training and invest time in the area of classroom management, teaching techniques and behavior. Student support, teaching methods, and presentation stand as important skills. Professional development for math instructors in schools in rural settings should be supported.

\section{Seeking Quality Schools}

The final domain found in the qualitative data gleaned from the investigation in Midville rests in the idea that the respondents seek a successful school. More to the point, the informants yearn for a school or school system that makes learning math an exciting, invigorating, and motivating experience. This desire surpasses a judgment of teacher's characters or their techniques. Midville folk believe that schools exist to serve the student and promote a strong, lively curriculum including effective lessons in math. Respondents, young and old, seek a quality school in the community so that they might be adequately or even completely prepared to move ahead in this ever-changing world.

\section{Quality Schools Example \#1}

As we begin to discuss math perceptions, Mr. Casual wastes no time as he shares his feelings. "Oh my godour schools aren't worth a s--- at teaching math!” he blurts out. He is immediately displays an anxious look, worrying that he has been too blunt. I give assurance that what I seek is honesty-that his choice of words causes no offense. "Don't let kids use calculators; they are one of the biggest problems with math education today. I had to learn how to do math on paper, but kids today can't add two and two without a calculator!" He is confident that "if high school curriculum required four years of math, many students who began with the opinion that math sucks, might find one enthusiastic teacher able to alter their thinking. The whole school experience can be salvaged by one teacher that makes a difference!” (Excerpt from a narrative by TSI)

\section{Quality Schools Example \#2}

"Now, as the parent of a child with a learning disability I see things from a different perspective. I realize first of all, how important education is, and as my wife and I struggle with what's best for our child we are sometimes confused by what goes on in the schools." He frowns now, and this simple conversation suddenly turns very serious. "Allow me to give you an example," he says. "I asked my child what $2 \times 12$ was, and she told me 40." And what do they want to try to teach her? Algebra! Please, if you can, enlighten me as to how that makes sense!”

"We no longer have time in the classrooms of today's schools to give a student individualized attention. Are we not all unique individuals who are therefore deserving of diversity in teaching styles?

We are all so very different-and yet we are all so much alike. Each of us has needs specific to who we are, what our particular standpoint is, as well as our level of intellect. Teaching (as well as learning) should focus on individualism... and until we step back a bit; until we are willing to place ourselves in a learning environment based on that thinking, we will continue to produce high school graduates with less than desirable life skills.” (Excerpt from a narrative by TSI)

\section{Quality Schools Example \#3}

She explains to me the first problem with the education system; "First off, small towns are all based on your last name; most people won't help you. My math teacher would always give preference to the cheerleader or the wealthier kid than to me [whenever I raise my hand in class]. I got into it with him before. I walked out of a class before because I am not one to feel degraded. I won't let anyone run over me! And I'll tell you this: I have nothing against sports, but education should stop focusing on athletics. If you're not into playing sports in this school, well then you may as well kiss your butt goodbye. I used to play high school sports and one time I failed a test, but the administration said 'that's okay; 
you can just take it over." She recalls how athletes got out of disciplinary action in her school and how the school believes that sports holds the most importance over any type of education. (Excerpt from a narrative by JT)

\section{Quality Schools Example \#4}

"Well, there were only 500 students in my entire high school. A lot of things I didn't understand. Teachers in the schools I don't think do a very good job around here. My grandson was having problems with decimals and where to place them. It became such a big problem that he was failing his math class. So we decided to put him in summer school. He works one on one with a teacher and the problem is solved within a week. Why couldn't his regular school do that for him?”

Her eyebrows lower, she crosses her arms and continues, "I think part of the problem is not enough hands-on work. I think the real question is how much of it's him and how much of the problem is the teacher, the environment, or the school program."

I probe more, trying to find out what she thinks the schools can do for the students. She pauses for a few seconds and looks down at the green carpet and says, "I think if teachers just spend time and explain it to the students. Maybe if they had to take a test before they start each school or grade level they could place them in the level of math they tested for and qualify in. And if they are at the bottom then they should put them in the most basic math class. Without basics, they don't have anything."

She begins talking particularly about the school system in Midville. She comments with a tone of annoyance in her voice, "Now see, my oldest son was in the weighted classes and was second in his class. They ended up dropping these classes right before graduation. When everyone was trying to get accepted into their colleges with the honors classes they were taking, well now they couldn't. They just dropped them with no warning and kids suffered.”

She uses her hands now, almost aggressively, and says, "A parent with the right name and right power has a kid who didn't take the honors classes so they decided that the weighted classes weren't important. But, because of this change, their child ended up moving up on the class rank. In other words, the discarded classes helped the status of the high class!” She shrugs her shoulders and says, "They just had the right name...that's a small town for ya.” (Excerpt from a narrative by RW)

\section{Quality Schools Example \#5}

"There should be absolutely no difference when it comes to the processes or techniques of teaching. Just because you live in the country or," she lifts her hands briefly in the air and mimics quotation marks, "out in the sticks." Sooner or later you will be competing with the students from the urban areas. Most of our kids don't stay around Midville anymore. It's like a little duck in a big pond.”

She continues, "The school systems need to be a lot stricter and demand more. If you demand more from the students, then you will get more from them. The more you expect, the more you get." There is a serious tone in her voice that becomes obvious as she talks about testing, "The programs, the lesson plans, the curriculum...It's all geared towards testing. You know it is." She shows her emotions through her hand gestures and continues, "All they want to prepare them for is the testing. They are teaching to the tests. I wish we could return to the days when schools could teach the subjects and not teach to the test.” (Excerpt from a narrative by RW)

The desire for quality mathematics instruction in schools is related to participants' responses to survey statement number eight_- "Our local schools do a good job in teaching math." Of the respondents surveyed, about 71\% agreed or agreed strongly with this statement. Sixty-nine percent of youth respondents agreed or strongly agreed that local schools were doing a good job teaching math, while $73 \%$ of all adult respondents echoed this same sentiment. Thus while individuals in Midville desire a quality school with friendly high quality mathematics instruction, a significant number of respondents seem to question how realistic these wishes are at this time (see Figure 7 below).

Informants from Midville believe that a successful math program makes a successful school. They believe that quality schools provide the basis for a successful community. Their values cause them to constantly seek superior schools through school board elections, funding, teacher recruitment, and parental involvement. Quality schools remain as the focus for the folk of Midville and math, they believe, features prominently as a major building block in this effort. 


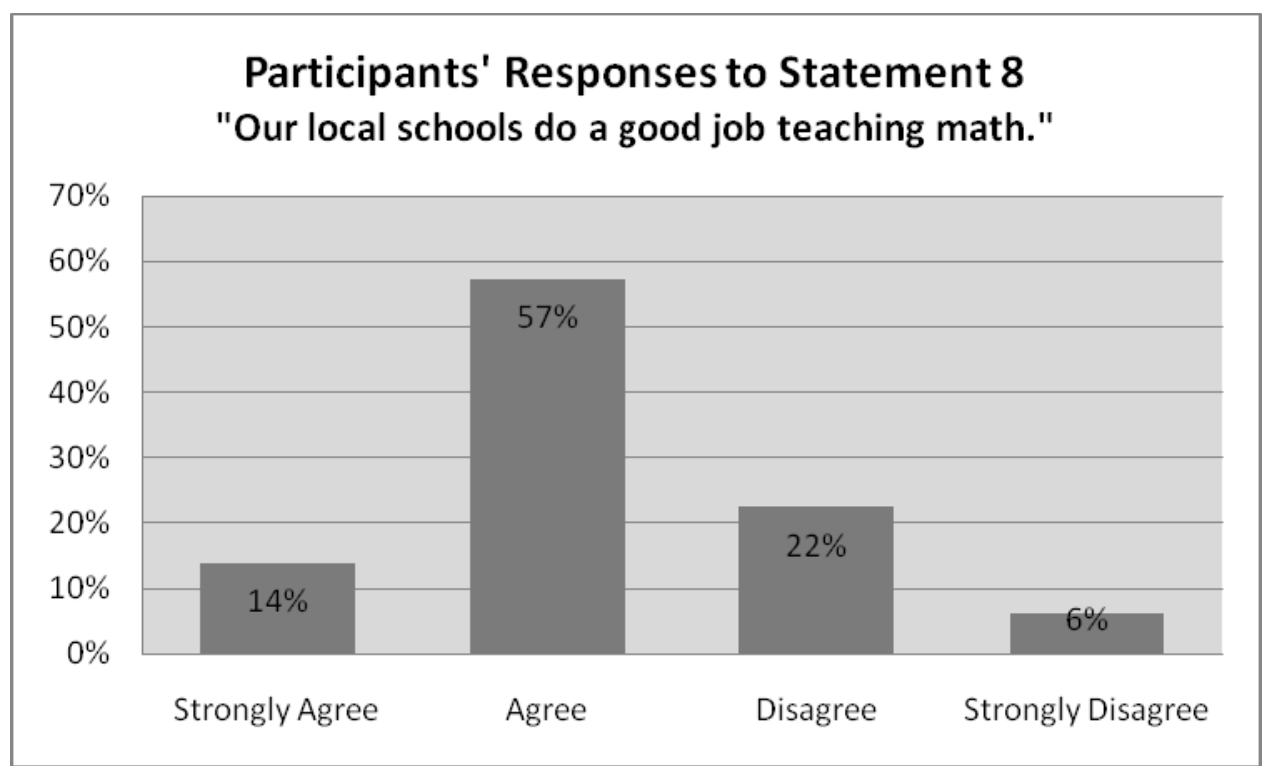

Figure 7. Participants' Responses to Statement Eight $(\mathrm{N}=1358)$

\section{Summary of Results}

The residents of Midville believe that a foundation of math education prepares a young person for success in college. Advanced education, they believe, offers youth a better and successful future. Math is viewed as the key for gaining stronger logic, better opportunities, and greater leverage in the world of academic competition. Math skills lead to more powerful careers.

This study revealed that many adults see schools as failing to offer effective math education as a result of too much emphasis on technology and not enough on arithmetic. The respondents do not fear the introduction of technology or technical tools into the classroom, but rather perceive that emphasis on technology, instead of mental computational skills, makes for weaker curriculum and instruction.

The folk tend to think that ill-tempered math teachers often create fear and poor attitudes in many of the students because of the pressure, criticism and negative behavior the teachers exhibit. The research reveals that math students wish for more positive, pleasant, kind instruction in their classroom environments in order to achieve the necessary math skills.

Adult respondents seem to confuse basic arithmetic with advanced math skills. Youth who cannot quickly add and subtract in everyday instances are viewed as math ignorant by many adult respondents while youth assert that arithmetic does not necessarily translate into a successful, modern math education. Modern math is viewed as complicated, detailed, and multi-dimensional.

Math teaching techniques were topics of conversation with folk as well as the management or actual governance of the school or the school system. Respondents yearn for math instructors that will create an enjoyable learning environment rather than a boring, repetitious, mentally painful experience. The folk of Midville seemed involved, informed, and interested in the teaching methods of their schools' math instructors. The respondents seek math instruction that challenges, inspires, and motivates the youth. According to the folk, they believe that quality schools offer a rigorous and comprehensive math education.

Folk of Midville hold that a comprehensive math education enhances an individual's opportunities, helps to establish good quality schools, and strengthens the overall success of the community and region. The folk of Midville, believe that math and math education deserve their attention, investment, and discipline. As one Midville high school senior said, "Math put us on the moon. There's no doubt that good math skills can take you a long way!"

\section{References}

Begg, A. (2004). Rethinking the image of mathematics. Public Understanding of Mathematics and Mathematics Education. ICME 10, DG7: Copenhagen, Denmark.

Bush, W. (2005). Improving Research on Mathematics Learning and Teaching in Rural Contexts [computer file]. Journal of Research in Rural Education, 20(8), 1.

COMPAS. (2004). Special Report on Teacher and Public Perceptions. Annual State of Education Survey, Commissioned by the Ontario College of Teachers. COMPAS, Inc. 
England, A. (2005). School board holds monthly meeting. Midville Daily Union*. Retrieved Jan 11, 2006. (*Pseudonym).

Fraser, A. Fleishauer, A. and O’Conner, M. (2004). Public to Policymakers: “More Math Please.” Boston, MA: Mass Insights Education and Research Institute.

Howley, A., Larson, W., Andrianaivo, S., Rhodes, M., \& Howley, M. (2007). Standards-based reform of mathematics education in rural high schools. Journal of Research in Rural Education, 22(2).

Howley, C., Howley, A., \& Huber, D. (2005). Prescriptions for rural mathematics instruction: Analysis of the rhetorical literature. Journal for Research in Rural Education, 20(7).

Howley, A., Pendarvis, E., \& Gholson, M. (2006). How talented rural students experience mathematics. Journal for the Education of the Gifted, 29(2), 123-160.

Interactive Illinois report card. (2006). Retrieved Jan. 11, 2006 from: http://iirc.niu.edu

International Institute of Folknography. www.folknography.com

Lott, J. W. (2004). Improving Perceptions of Mathematics Education through Political Action. National Council of Teachers of Mathematics.
Lucas, D. M. (2004). The Perceptions of the Importance of Math and Math Education in Appalachia. http://www.acclaimmath.org/docs/monographs/Monograp h_01_Lucas.pdf

Lucas, D. M. (2005). The Handbook of Folknography: A Qualitative Research Method for Giving Voice. Pearson Publishing Boston, MA.

MacDonald, J. (2004). Contrarian Finding: Computers are a drag on learning. (Learning Section) Christian Science Monitor, 97(7), 11.

State and county quickfacts. (n.d.). U.S. Census Bureau. Retrieved Jan. 15, 2006 from: http://quickfacts.census.gov/qfd/states/17000.html.

Snyder, B. (2006). Mathematics-We're Counting on Helpfrom the Parents. PC-Calculators.Com.

Watt, H.M.G. (2004). Development of Adolescents' Self Perceptions, Values and Task Perceptions According to Gender and Domain in 7th through 11th Grade Australian Students. Child Development, 75(5).

Weintraub, I. (2004). What's the difference between arithmetic and math?, MathMedia Educational Software, Inc. 